\title{
Appealability of a Class Action Dismissal: The "Death Knell" Doctrine
}

The burgeoning of the class action device in both federal ${ }^{1}$ and state $^{2}$ courts has significantly expanded the opportunities for parties with relatively small individual damage claims ${ }^{3}$ to obtain judicial relief. Limited financial resources ${ }^{4}$ and potentially small recovery ${ }^{5}$ usually make litigation of individual claims impractical. ${ }^{8}$ For the typical plain-

1 See, e.g., Kaplan, Continuing Work of the Civil Committee: 1966 Amendments of the Federal Rules of Civil Procedure (I), 81 HARv. L. REv. 356 (1967); Wright, Class Actions, 47 F.R.D. 169 (1969); Comment, The Impact of Class Actions on Rule 10b-5, 38 U. CHI. L. REv. 337 (1971); Note, Federal Rules of Civil Procedure: Rule 23, The Class Action Device and Its Utilization, 22 U. FLA. L. REV. 631 (1970).

2 See, e.g., Homburger, State Class Actions and the Federal Rule, 71 Colum. L. REv. 609 (1971); Comment, Expanding the Impact of State Court Class Action Adjudications to Provide an Effective Forum for Constrmers, 18 U.C.L.A.L. REv. 1002 (1971).

3 See Kaplan, supra note 1, at 397-98. According to Professor Kaplan, the Reporter for the latest revision of the federal class action rule, the "historical mission" of the class action device has been to "[take] care of the smaller guy." Frankel, Amended Rule 23 from a Judge's Point of View, 32 AnTtrRust L.J. 295, 299 (1966). See also Ford, Federal Rule 23: A Device for Aiding the Small Claimant, 10 B.C. IND. \& CoM. L. REv. 501 (1969).

4 With respect to the famous electrical antitrust cases of 1961, for example, it was noted that "[t]he reason for the lack of heavy resort to rule 23 [the federal class action rule] was that lawyers apprehended that where the claims are large and the individual claimants willing and able to take care of themselves, there is reason for bypassing the class-action procedure." Kaplan, The Impact of the Electrical Anti-Trust Cases upon Federal Civil Procedure, 39 F.R.D. 495, 517 (1965). See also Frankel, supra note 3, at 298.

5 E.g., Ill. Bell Tel. Co. v. Slattery, 102 F.2d 58 (7th Cir.), cert. denied, 307 U.S. 648 (1939). This was a utility rate case with a final distribution of $\$ 17$ million in refunds to more than one million persons in which eighty-five percent of all claims were less than $\$ 25$ each. Kalven \& Rosenfield, The Contemporary Function of the Class Suit, 8 U. CHI. L. REv. 684, 686 n.5 (1941).

6 "[T]t [takes] no great understanding of the mysteries of high finance to make obvious the futility of spending a thousand dollars to get a thousand dollars-or even less." Douglas, Protective Committees in Railroad Reorganizations, 47 HARv. L. REv. 565, 567 (1934). "Moreover, almost no single investor's stake would warrant the enormous expense of his seeking legal redress." Kalven \& Rosenfield, supra note 5, at 685.

The law of our state [New York] and of all states and the nation as well, has often been hyprocritical as far as the consumer is concerned. It gives him rights, but then creates economic barriers so high that it is impossible to enforce those rights. It tells him to spend thousands of dollars on a lawsuit to recover hundreds of dollars which he lost in a swindle.

Schrag, The Rights of Consumers, in The Rughts of AmEricans 128, 135 (N. Dorsen ed. 1971) (statement of Bess Myerson Grant, Commissioner of Consumer Affairs, New York City). See also Escort v. Bar-Chris Constr. Co., 340 F.2d 731, 733 (2d Cir.), cert. denied sub nom. Drexel \& Co. v. Hall, 382 U.S. 816 (1965):

In our complex modern economic system where a single harmful act may result in damages to a great many people there is a particular need for the representative 
tiff in a stockholders' or consumers' suit, moreover, alternative procedural devices such as intervention, ${ }^{7}$ joinder, ${ }^{8}$ consolidation, ${ }^{9}$ and the test case ${ }^{10}$ provide little assistance in overcoming the problem of legal expenses. Aggregation of damages through the class action device, ${ }^{11}$ on the other hand, enables the plaintiff to attract competent counsel.12

action as a device for vindicating claims which, taken individually, are too small to justify legal action but which are of significant size if taken as a group. In a situation where we depend on individual initiative, particularly the initiative of lawyers, for the assertion of rights, there must be a practical method for combining these small claims, and the representative action provides that method. The holders of one or two of the debentures involved in the present action could hardly afford to take the risk of an individual action. The usefulness of the representative action as a device for the aggregation of small claims is "persuasive of the necessity of a liberal construction of * * Rule 23." Weeks v. Bareco Oil Co., 125 F.2d 84 (7th Gir. 1941) . . .

7 See generally 3B J. MOORE, FEDERAL Practice If 24.01-.20 (2d ed. 1969).

8 See generally id. 99 18.01-.11; Tone \& Stifler, Joinder of Parties and Consolidation of Multiparty Actions, 1967 InL. L.F. 209.

9 See $5 \mathrm{~J}$. MOORE, supra note 7, II 42.01-.02.

10 See 3B J. MOORE, supra note 7, I 23.45[3]; Schrag, Bleak House 1968: A Report on Consumer Test Litigation, 4 N.Y.U.L. REv. 115 (1969).

11 There are many areas of federal law under which class suits have routinely been brought and where the jurisdictional statutes provide entry to the federal courts without regard to the amount in controversy. E.g., 28 U.S.C. \& 1334 (1970) (bankruptcy matters and proceedings); 28 U.S.C. § 1337 (cases arising under any act of Congress regulating commerce) (1970); 28 U.S.C. § 1343 (1970) (civil rights cases); 28 U.S.C. $\S 1353$ (1970) (cases involving Indian allotments). See generally C. Wright, LAw OF FEDERAx CourTs $\$ 32$ (2d ed. 1970).

Where entry into the federal courts is based on the diversity-of-citizenship statute, 28 U.S.C. $\S 1332$ (1970), an amount in controversy exceeding ten thousand dollars must be pleaded. Despite the 1966 revision of the federal class action rule, FED. R. Crv. P. 23, it was held in Snyder v. Harris, 394 U.S. 332 (1969), that, if the amount were reached by an aggregation of claims, it would confer jurisdiction only where the claims were joint as opposed to several and distinct. That ruling followed the preexisting law on the subject. Clark v. Paul Gray, Inc., 306 U.S. 583 (1939); Pinel v. Pinel, 240 U.S. 594 (1916). The Snyder ruling was objected to by the Reporter of the revision of Rule 23, Professor Kaplan. Kaplan, A Prefatory Note to a Symposium on Rule 23, 10 B.C. IND. \& CoM. L. REV. 497 (1969). See the Revision Committee's Note of 1966 to Rule 23 in 3B J. MOORE, supra note 7, ๆๆ 23.01(8)-(13). See also Wright, supra \& 36; Maraist \& Sharp, After Snyder v. Harris: Whither Goes the Spurious Class Action, 41 Mrss. L.J. 379 (1970); Comment, supra note 2, at 1002.

12 The proposition that a settlement or recovery benefiting a class should in fairness require all class members to assist in the compensation of victorious counsel is an old one. Trustees v. Greenough, 105 U.S. 527 (1882). The rationale has been carried forward to encompass compensation for the litigators from common funds established after a successful first case in later actions where res judicata, collateral estoppel, or stare decisis allowed other plaintiffs similarly situated to benefit from their legal acumen. The leading case allowing such compensation is Sprague v. Ticonic Nat'1 Bank, 307 U.S. 161 (1939).

Where a common fund has been brought into existence by the successful prosecution of a class action, the court has the discretionary power to award attorneys' fees to be paid out of the fund. In that way, all members of the represented class share in the expense attendant upon their receiving the fund. See Note, The Cost-Internalization Case for Class Actions, 21 StAN. L. REv. 383, 403 (1969). See generally 3B J. MoORE, supra note 7, 
Thus, for the small-claim plaintiff, the most important consequence of the availability of the class action device is that it often determines whether litigation of his claim is economically feasible. ${ }^{13} \mathrm{~A}$ critical problem therefore arises when the trial court, exercising its discretion under rule 23 of the Federal Rules of Civil Procedure, orders the dismissal of the class action but permits the plaintiff to prosecute his individual claim. ${ }^{14}$ At present, most jurisdictions regard a class action dismissal as interlocutory and thus not immediately appealable under section 1291 of the Judicial Code. ${ }^{15}$ The named plaintiff is consequently required to await a final judgment on the merits of the case before the order may be reviewed.16 Two possible effects ensue from this rule.

I 23.91; Comment, The Allocation of Attorneys' Fees After Mills v. Electric Auto-Lite Co., 38 U. CHI. L. REv. 316 (1971).

Commentators have long recognized both the salutory and the capitalistic considerations which go into the making of a class action. On the one hand, the device has been seen as a way to redress efficiently group wrongs by private civil action and thereby to provide a needed supplement to the prosecutorial activities of governmental agencies. E.g., J. I. Case v. Borak, 377 U.S. 426, 432 (1964); Associated Industries v. Ickes, 134 F.2d 694 (2d Cir.), vacated as moot, 320 U.S. 707 (1943); Hornstein, Legal Therapeutics: The "Salvage" Factor in Counsel Fee Awards, 69 HARv. L. REv. 658 (1956). On the other hand, it has been noted that, no matter what the impact as yet on the average consumer, the increased use of the class action device is "clearly a boon for lawyers." Shaffer, More Antitrust Suits Are Filed by States, Firms, Private Parties, Wall Street Journal, Jan. 18, 1972, at 1, col. 6; see Freeman, Attorneys" Fees: A Search for a "Rule of Reason," 38 ANTrTRust L.J. 721, 727 (1969). See also Dolgow v. Anderson, 43 F.R.D. 472, 487, 495 (E.D.N.Y. 1968): Those who criticize the class action on the grounds that it stirs up plaintiffs and serves only to provide fees for attorneys overlook the fact that we not not dealing with the traditional lawsuit which concerns primarily those litigants before the court.

-...

... Quite obviously, a major incentive to forceful prosecution is the substantial counsel fee plaintiffs' attorney believes he may be awarded if he is successful.

13 See, e.g., Dolgow v. Anderson, 43 F.R.D. 472, 485 (E.D.N.Y. 1968): "On oral argument in the present case, it was assumed that, in view of the fact that the costs of the litigation would far exceed any damages the individual plaintiffs might possibly recover, if this case does not proceed as a class action, it is unlikely that it would proceed at all."

14 Under FED. R. Grv. P. 23, the named plaintiff must satisfy several requirements in order to prosecute his suit as a class action: (1) the class alleged must be so numerous that joinder of all members would be impracticable, (2) there must be questions of law and fact common to the class, (3) the claims and defenses of the named plaintiff must be typical of those of the class, (4) the named plaintiff and his counsel must be able to protect fairly and adequately the interests of the class, (5) the questions of law and fact common to the class must predominate over those affecting individuals within the class, and (6) the class device must be superior to other available methods for the fair and efficient adjudication of the controversy. See generally Wright, supra note 1 , at 169.

15 See text and notes at notes 22-26 infra.

16 Such orders do not merge in the final decree, and a successful named plaintiff may appeal based on his interest in sharing expenses with other members of the alleged class. See Esplin v. Hirschi, 402 F.2d 94 (10th Cir. 1968), cert. denied, 394 U.S. 928 (1969) (cross- 
First, if the named plaintiff's claim is small, prolonged litigation will make the potential costs of the suit prohibitive. The named plaintiff will be forced to discontinue the suit, effectively leaving both him and the other members of the alleged class without a legal remedy. Second, even if his claim is large enough to induce continued prosecution of the action to a judgment on the merits, there is still no assurance that the named plaintiff will eventually appeal the class action dismissal. If the named plaintiff prevails, he may well be content to terminate the suit after recovery of his own damages. For another member of the alleged class to intervene in the suit at that time, for the purpose of taking an appeal, is a move fraught with legal and practical difficulties. ${ }^{17}$ And attempts by other alleged class members to benefit from any precedential or collateral estoppel effect of the suit will confront the same financial problems which, as a practical matter, made an individual action unattractive initially. In sum, the other alleged class members will still have been denied an effective method of recovery.

In response to these considerations, courts have begun to reappraise the traditional interlocutory characterization of trial court orders dismissing class actions and have come to regard them as final judgments immediately appealable by the named plaintiff. ${ }^{18}$ This has occurred, however, only where the disparity between litigation costs and the size of the potential judgment prohibit both the named plaintiff and the other members of the alleged class from maintaining individual actions. ${ }^{19}$ By contrast, where the named plaintiff is left with an economically viable individual action, no change in the traditional rule has been permitted..$^{20}$ Furthermore, only the named plaintiff is allowed to appeal from the class action dismissal. ${ }^{21}$

This comment will examine the developing approaches of appellate courts with respect to the appealability of trial court orders dismissing class actions. Section I considers the boundaries of the "one final judgment" rule and the flexibility of application afforded the courts by case law exceptions to it. Section II analyzes the effectiveness of an attempt to interpret the rule to permit immediate appeal by the named plaintiff with a small individual claim - the Second Circuit's "death knell" doctrine-and discusses the advantages and limitations of expansion of

appeal by successful plaintiff. See generally Wright, supra note 11, §§ 101-02; Crick, The Final Judgment as a Basis for Appeal, 41 YALE L.J. 539 (1932); Frank, Requiem for the Final Judgment Rule, 45 TExas L. REv. 292 (1966).

17 See note 90 infra.

18 See text and notes at notes 60-86 infra.

19 See text and notes at notes $64-65,67-68,80$ infra.

20 See text and notes at notes 70-72, 77, 80-83 infra.

21 See note 90 infra. 
the death knell doctrine to allow immediate appeal whenever dismissal threatens to foreclose relief for any other member of the alleged class.

\section{The One Final Judgment Rule and Its Exceptions}

Absent a specific statutory ${ }^{22}$ or case law ${ }^{23}$ exception, section 1291 of the Judicial Code $^{24}$ and state statutory equivalents ${ }^{25}$ limit appeal to final decisions on the merits of a case. This principle is often expressed as the "one final judgment" or "finality" rule and is based on the public policy disfavoring piecemeal appeals as a potential source of harassment of litigants and delay in the resolution of controversies. ${ }^{26}$ The demand for equitable results in particular cases, however, has caused the gradual erosion of the one final judgment rule in several respects. ${ }^{27}$ Professor Moore suggests that "for nearly each general principle of finality there is a competing principle or qualification. And, in truth, at times the rule of finality permits interlocutory appeals under the guise of 'finality." "28 At present, final judgments commonly include orders in cases in which further action is still required for a complete determination of all rights. ${ }^{29}$

The appealability of an admittedly interlocutory order is expressly provided by statute with respect to several types of trial court orders.

22 E.g., 28 U.S.C. \$ 1292 (1970); CAL. Grv. Pro. Code § 904.1 (Deering 1959); cf. FED. R. Crv. P. 54(b); Sears, Roebuck \& Co. v. Mackey, 351 U.S. 427 (1956).

23 E.g., Mills v. Alabama, 384 U.S. 214 (1966); Gillespie v. United States Steel Corp., 379 U.S. 148, 153 (1964); Construction \& Gen'l Laborers Local 438 v. Curry, 371 U.S. 542 (1963); Cohen v. Beneficial Indus. Loan Corp., 337 U.S. 541 (1949).

2428 U.S.C. § 1291 (1970); see 6 J. MooRE, supra note 7, If 54.04-19.

25 E.g., Cal. Crv. Pro. Code § 963(1) (Deering 1959); see Bakewell v. Bakewell, 21 Cal. 2d 224, 226, 130 P.2d 975, 977 (1942). See also, e.g., Comment, Appealable Judgments Under the Indiana Rules of Civil Procedure, 2 IND. L.J. 363 (1969); Comment, Civil Procedure"Final Judgment Rule" in Workmen's Compensation Cases, 8 NAT. REsources J. 522 (1968).

26 See, e.g., Andrews v. United States, 373 U.S. 334, 340 (1963); Catlin v. United States, 324 U.S. 229, 233-34 (1945); Cobbledick v. United States, 309 U.S. 323, 324-25 (1940). This policy was first declared in the Judiciary Act of $1789, \S 22,1$ Stat. 73, and is carried forward today in 28 U.S.C. 1291 (1970), giving the courts of appeals "jurisdiction of appeals from all final decisions of the district courts ...." See 9 J. MOoRE, supra note 7, \ 110.07 .

27 See generally Frank, supra note 16. As Mr. Justice Jackson observed in Dickinson v. Petroleum Conversion Corp., 338 U.S. 507, 511 (1950), the courts have struggled

sometimes to devise a formula that will encompass all situations and at other times to take hardship cases out from under the rigidity of previous declarations; sometimes choosing one and sometimes another of the considerations that always compete in the question of appealability, the most important of which are the inconveniences and costs of piecemeal review on the one hand and the danger of denying justice by delay on the other. [5].

$286 \mathrm{~J}$. MOORE, supra note 7, I 54.04[2], at 148; see 6 J. MOORE, supra note 7, II 54.43[2],

29 See, e.g., Forgay v. Conrad, 47 U.S. (6 How.) 201 (1848); Cohen v. Beneficial Indus. Loan Corp., 337 U.S. 541 (1949); 28 U.S.C. \$§ 1651, 1292 (1970); FED. R. Giv. P. 54(b). 
Section 1292(a), for example, permits the immediate appeal of certain injunctions and various receivership, admiralty, bankruptcy, and patent infringement matters. ${ }^{30}$ Section 1292(b) permits the trial court, in its discretion, to certify for immediate appeal controlling questions of law as to which the authorities are in conflict and whose resolution would materially advance the progress of the litigation. ${ }^{31}$ An attempt to appeal a nonappealable order may also, in the court's discretion, be treated as a petition under the All Writs Act. ${ }^{32}$ A final statutory exception unknown to the common law ${ }^{33}$ is contained in rule 54(b) of the Federal Rules of Civil Procedure, which allows an appeal, upon the trial court's determination that there is no just cause for delay, from a judgment respecting fewer than all the claims or parties in an action. ${ }^{34}$

Despite the existence of these statutory provisions authorizing appeals of interlocutory orders, courts have utilized them only infrequently in dealing with the named plaintiff denied class representative status. ${ }^{35}$

3028 U.S.C. § 1292(1) (1970); see 9 J. Moore, supra note 7, If 110.16-21. Similar exceptions exist in state law. E.g., CAL. Civ. Pro. Code \& 904.1 (Deering 1959) (allowable upon order of money payments or the performance of an act); see Sjoberg v. Hastorf, 33 Ca1.2d 116, 119, 199 P.2d 668, 670 (1948).

3128 U.S.C. § 1292(b) (1970); see Cord v. Smith, 338 F.2d 516, 521 (9th Cir. 1964), mandate clarified, 370 F.2d 418 (1966):

Of course, the principal purpose of section 1292(b) is to permit appeals, with the concurrence of the trial court and of the court of appeals, from interlocutory orders not appealable under section 1292(1). But the existence of this method of appeal also removes any incentive to enlarge by a liberal construction, the class of orders appealable under section $1292(\mathrm{a})$.

3228 U.S.C. § 1651 (1970); 9 J. MOORE, supra note 7, I 110.26. See also Wright, The Interlocutory Appeals Act of 1958, 23 F.R.D. 199 (1959); Note, Appealability in the Federal Courts, 75 HARV. L. REv. 351, 379 (1961).

33 Under the common law theory of the "single judicial unit," each action was considered a single unit, and all judgements lacked finality for the purpose of appeal until the unit was adjudicated in its entirety. Sheppy v. Stevens, 200 F. 946 (2d Cir. 1912); Metcalf's Case, 77 Eng. Rep. 1193, 1196 (1615).

34 FED. R. Crv. P. 54(b); see 6 J. MOORE, supra note 7 , IT 54.26-.29. The courts of appeals have not been reticent about refusing to review a judgment under rule 54(b) when they have felt that the district court abused its discretion in entering the final judgment order for that portion of the case. $6 \mathrm{~J}$. MOoRE, supra note 7, I 54.41[3] n.50. This exception to the one final judgment rule is also followed in the state courts. E.g., Howe v. Key System Transit Co., 198 Cal. 525, 246 P. 39 (1926).

35 E.g., Interpace Corp. v. City of Philadelphia, 438 F.2d 401 (3d Cir. 1971) (petition for writ of mandamus to require order allowing class action to be certified appealable under section 1292(b) denied); Johnson v. Georgia Hy. Express, Inc., 417 F.2d 1122 (5th Cir. 1969) (appeal allowed under section 1292(b) from order allowing allegations covering a class substantially narrower than requested by named plaintiff); Oatis v. Crown Zellerbach Corp., 398 F.2d 496 (5th Cir. 1968) (appeal allowed under rule 54(b) from an order allowing class action but dismissing certain plaintiff parties); Hayes v. Sealtest Foods Div. of Nat'l Dairy Prods. Corp., 396 F.2d 448 (3d Cir. 1968) (order striking class action allegations appealable if certified under rule 54(b)); Brunson v. Board of Trustees, 311 F.2d 107 (4th Cir. 1962), cert. denied, 373 U.S. 933 (1963) (order striking class action allegations 
Instead, such a plaintiff has usually been required to demonstrate that the dismissal of his class action fits within the final judgment category. ${ }^{36}$ Two major case law exceptions to the one final judgment rule have, however, softened the traditional rigidity of this requirement. ${ }^{37}$

Under the first exception, recognized by the Supreme Court in Forgay v. Conrad, ${ }^{38}$ courts have held that orders subjecting parties to "irreparable injury" are final for purposes of review. ${ }^{39}$ The cases admit, however, that the orders held appealable would generally be considered interlocutory. ${ }^{40}$ The Forgay exception has been used to allow appeal from orders requiring the delivery of title to a canal, ${ }^{41}$ setting aside a radio station lease, ${ }^{42}$ requiring the conveyance of a part interest in certain oil and gas leases, ${ }^{43}$ cancelling certain oil and gas leases, ${ }^{44}$ and the like. ${ }^{45}$

The more important case law exception to the finality rule was established by the Supreme Court in Cohen $v$. Beneficial Industrial Loan Corp., ${ }^{48}$ under which courts have allowed, in certain circumstances, the severability and immediate appeal of a "collateral order," even though other issues in the case remain to be decided.47 In the words of the Cohen court:

This decision appears to fall in that small class which finally determines claims of right separable from, and collateral to rights asserted in the action, too important to be denied review and too

in a desegregation suit tantamount to denial of requested injunctive relief and thus appealable under section 1292).

36 See 6 J. MOORE, supra note 7, $9 \mathbb{T}$ 54.30-.32; 3 W. Barron \& A. Holtzoff, Federal Practice and Procedure \$\$ 1193-93.2 (C. Wright ed. 1958); Note, supra note 32, at 357-63.

37 See 7B J. MOORE, supra note 7, \& 1291, at 415-18; Frank, supra note 16, at 295-305; Comment, The One Final Judgment Rule-A Fundamental Principle of Appellate Practice in California, 15 Hastincs L.J. 93, 100-01 (1963); Note, supra note 32, at 364-67.

3847 U.S. (6 How.) 201 (1848). See generally 9 J. MOORE, supra note 7, ๆ 110.11.

39 E.g., Carondelet Canal \& Navigation Co. v. Louisiana, 233 U.S. 362 (1914).

40 E.g., Republic Gas v. Oklahoma, 334 U.S. 62, 68 (1948); Craighead v. Wilson, 59 U.S. (18 How.) 199, 202 (1855).

11 Carondelet Canal \& Navigation Co. v. Louisiana, 233 U.S. 362 (1914). But see California Nat'I Bank v. Stateler, 171 U.S. 447 (1898).

42 Radio Station WOW v. Johnson, 326 U.S. 120 (1945).

43 Kasishke v. Baker, 144 F.2d 384 (10th Cir. 1944), cert. denied, 325 U.S. 856 (1945).

44 Delta Drilling Co. v. Arnett, 186 F.2d 481 (6th Cir. 1950).

45 E.g., United States v. Certain Real Estate, 217 F.2d 920 (6th Cir. 1954); Durkin v. Mason \& Dixon Lines, 202 F.2d 425 (6th Cir. 1953); Biggins v. Oltmer Iron Works, 154 F.2d 214 (7th Cir. 1946).

40337 U.S. 541 (1949).

47 E.g., Larson v. Domestic \& Foreign Corp., 337 U.S. 682, 685 n.3 (1949); Forsyth v. Hammond, 166 U.S. 506, 513 (1897). This case law exception is also followed in the state courts. Southern Pac. Co. v. Oppenheimer, 54 Cal. 2d 784, 785-86, 356 P.2d 441, 442, 8 Cal. Rptr. 657, 658 (1960); Lukens, The Collateral Order Doctrine in California, 15 HASTINGS L.J. 105 (1963). 
independent of the cause itself to require that appellate consideration be deferred until the whole case is adjudicated. The Court has long given this provision [section 1291] this practical rather than a technical construction. ${ }^{48}$

As with Forgay, the Cohen case has engendered a plethora of decisions attempting, without notable success, to define the exception in a precise and systematic fashion..$^{49}$ The case law authority appears split, for example, on whether a collateral order under Cohen requires certification by the trial judge before an appeal may be taken.50 Nevertheless, Cohen has been invoked to permit immediate appeal of a wide array of interlocutory orders, including orders refusing to impose a lien for attorneys' fees pendente lite, ${ }^{51}$ dismissing a petition for removal of an administrator, ${ }^{52}$ directing the production of bank examination reports that were allegedly the subject of executive privilege, ${ }^{53}$ and vacating an order approving a stipulation dismissing an appeal. ${ }^{54}$ As such cases indicate, Cohen has been interpreted to allow appeal even when there has been no showing of "serious public consequences;" 55 consideration thought to be a limitation on the use of the Forgay exception. ${ }^{56}$

Significantly, the most recent Supreme Court case interpreting the

48337 U.S. at 546.

49 E.g., Travelers Indem. Co. v. Miller Mfg. Co., 276 F.2d 955 (6th Cir. 1960) (order granting separate trial of issues raised in complaint and third-party complaint nonappealable); MacAlister v. Guterma, 263 F.2d 65 (2d Cir. 1958) (order denying consolidation of three stockholders' suits for pretrial proceedings appealable); City of Los Angeles v. Los Angeles City Water Co., 134 Cal. 121, 66 P. 198 (1901) (order settling accounts of a receiver appealable). See also Mutual Reserve Fund Life Ass'n v. Smith, 169 Ill. 264, 48 N.E. 208 (1897); Rosenthal v. Rosenthal, 39 Nev. 74, 153 P. 91 (1915); Ryan v. Kroger Grocery \& Baking Co., 56 Ohio App. 469, 11 N.E.2d 204 (1937).

50 E.g., Redding \& Co. v. Russwine Constr. Corp., 417 F.2d 721, (D.C. Cir. 1969) (certificate not required); Moses Lake Homes, Inc. v. Grant County, 276 F.2d 836 (9th Cir.), rev'd on other grounds, 356 U.S. 744, rehearing denied, 366 U.S. 947 (1960) (certificate required); Lyman v. Remington Rand, Inc., 188 F.2d 306 (2d Gir. 1951) (certificate required).

51 Preston v. United States, 284 F.2d 514 (9th Cir. 1960).

52 Collins v. Miller, 198 F.2d 948, 951 (D.C. Cir. 1952).

53 Overby v. United States Fidelity \& Guaranty Co., 224 F.2d 158 (5th Cir. 1955).

54 Weilbacher v. J.H. Winchester \& Co., 197 F.2d 303 (2d Cir. 1952).

55 The Second Gircuit has suggested that the doctrine should perhaps be limited to situations in which the questions presented are of generalized importance, extending beyond the parochial concerns of the particular litigants. Donlon Industries v. Forte, 402 F.2d 935, 937 (2d Cir. 1968). While the Supreme Court has not yet ruled on this proposed limitation, earlier cases did not adopt such a constriction of the Cohen exception. See, e.g., Stack v. Boyle, 342 U.S. I (1951) (order refusing to reduce bail appealable); Roberts v. United States District Court, 339 U.S. 844 (1950) (order refusing a plaintiff leave to proceed in forma pauperis appealable). See also Gillespie v. United States Steel Corp., 379 U.S. 148 (1964).

56 See Radio Station WOW v. Johnson, 326 U.S. 120, 124 (1945). 
Cohen exception seems to have expanded its scope. In Gillespie $\boldsymbol{v}$. United States Steel Corp. ${ }^{\text {s7 }}$ the Court allowed appeal of a trial court order dismissing certain state wrongful death claims while permitting a Jones Act claim to go to trial. The Court's opinion appears to raise serious questions concerning the continued vitality of the finality doctrine. ${ }^{58}$ Professor Moore has suggested that Gillespie departs from the Forgay and Cohen holdings and establishes the principle that, even if the order in the case is not final, appeal will be permitted where the issue of appealability vel non is closely divided and the questions raised are "fundamental to the further conduct of the case." Interestingly, this appears to be the same policy that Congress sought to promote through the certification procedure of section 1292(b).

\section{The Second Gircuit's "Death Knell" Doctrine}

On the federal level, only the Second Circuit has utilized the Forgay and Cohen exceptions to the one final judgment rule in reappraising the traditional interlocutory characterization of trial court orders dismissing class actions. Eschewing the statutory devices and procedural exceptions favored by other circuits, ${ }^{60}$ the Second Circuit has focused on the economic viability of the named plaintiff's remaining individual claim as the critical factor in determining the appealability of a class action dismissal. ${ }^{61}$ In essence, the court's "death knell" doctrine states

57379 U.S. 148 (1964).

58 "The opinion upholding appealability in Gillespie ... is enough to put an end to the whole notion of finality." D. CURRIE, FEDERAL CourTs: CASES AND MATERIALs 231 (1968).

$699 \mathrm{~J}$. MOORE, supra note 7, I 110.12, at 150, quoting Gillespie v. United States Steel Corp., 379 U.S. 148, 154 (1964); cf. Larson v. Domestic \& Foreign Corp. 337 U.S. 682 (1949).

60 See cases cited supra note 35.

61 Eisen v. Carlisle \& Jacquelin, 370 F.2d 119 (2d Cir. 1966), cert. denied, 395 U.S. 977 (1969); Green v. Wolf Corp., 406 F.2d 291 (2d Cir. 1968), cert. denied, 395 U.S. 977 (1969); City of New York v. International Pipe \& Ceramics Corp., 410 F.2d 295 (2d Cir. 1969); Caceres v. International Air Transport Ass'n, 422 F.2d 141 (2d Cir. 1970); Korn v. Franchard Corp., 443 F.2d 1301 (2d Cir. 1971); Milberg v. Western Pac. Ry. Co., 443 F.2d 1301 (2d Cir. 1971).

The Second Circuit had rejected the notion of appealability of orders dismissing class actions under the pre-1966 FED. R. Crv. P. 23. Lipsett v. United States, 359 F.2d 956 (2d Cir. 1966). Its more recent stance has been explicitly followed only by the district courts in the Second Circuit, e.g., Fogel v. Wolfgang, 47 F.R.D. 213 n.4 (S.D.N.Y. 1969); Dolgow v. Anderson, 43 F.R.D. 472, 485 (E.D.N.Y. 1968), and by the Ninth Circuit, Weingartner v. Union Oil Co., 431 F.2d 26, 29 (9th Cir. 1970), cert. denied, 400 U.S. 1000 (1971). It has been rejected by the Third Circuit. Hackett v. General Host Corp., No. 19,320 (3d Cir., Jan. 14, 1972). See also Hohmann v. Packard Instrument Co., 399 F.2d 711 (7th Cir. 1968); Zahn v. International Paper Co., 53 F.R.D. 430 (D. Vt. 1971).

The California state courts have also looked to the economic viability of the remaining individual suit where a plaintiff has attempted an immediate appeal of a class action dismissal. In Daar v. Yellow Cab Co., 67 Cal. 2d 695, 715, 433 P.2d 732, 746, 63 Cal. Rptr. 
that, where the named plaintiff's claim would be too small, considering litigation costs and the size of the potential judgment, to warrant prosecution individually, the dismissal should be deemed a final judgment and thus immediately appealable. ${ }^{82} \mathrm{On}$ the other hand, where it appears that the named plaintiff's claim is sufficiently large, as a practical matter, to warrant prosecution individually, the dismissal should be considered a nonappealable interlocutory order. ${ }^{63}$

\section{A. Development of the Present Rule}

The first of the Second Circuit cases propounding the death knell doctrine was Eisen $v$. Carlisle \& Jacquelin. ${ }^{64}$ There, an investor had brought an action in his individual capacity and on behalf of all oddlot securities traders, alleging antitrust violations on the part of two major odd-lot dealers. On the defendant's motion, the district court dismissed the class action, leaving the named plaintiff with a seventy dollar claim. The Second Circuit allowed an immediate appeal, finding that the dismissal was a collateral order falling within the Cohen exception to the final judgment rule. The court viewed the dismissal as a concluded claim of right which fell within the "twilight zone" of finality noted in Gillespie and, accordingly, applied a "practical" rather than a "technical" construction of the rule:

The order dismissing this class action is appealable. The alternatives are to appeal now or to end the law suit for all practical purposes. ... We can safely assume that no lawyer of competence is going to undertake this complex and costly case to recover $\$ 70$ for Mr. Eisen. ... Where the effect of a district court's order, if not

724,738 (1967), it was alleged that taxi meters had been set to charge an illegally high fare:

[A]bsent a class suit, recovery by any of the individual taxicab users is unlikely. The complaint alleges that there is a relatively small loss to each individual class member. In such a case separate actions would be economically unfeasible. Joinder of plaintiffs would be virtually impossible in this case. It is more likely that, absent a class suit, defendant will retain the benefits from its alleged wrongs. A procedure that would permit the allegedly injured parties to recover the amount of their overpayment is to be preferred over the foregoing alternative. [Emphasis added.]

Economic viability was also taken into consideration in Gerhard v. Stephens, 68 Cal. 2d 864, 913, 441 P.2d 692, 728, 69 Cal. Rptr. 612, 648 (1968), and Slakey Bros. Sacramento, Inc. v. Parker, 265 Cal. App. 2d 204, 205 n.l, 210, 71 Cal. Rptr. 269, 270 n.1, 275 (1968); cf. Weingartner v. Union Oil Co., 431 F.2d 26, 29 (9th Cir. 1970) (class action denied where fifteen plaintiffs had combined stake of $\$ 353,700)$.

62 Eisen v. Carlisle \& Jacquelin, 370 F.2d 119 (2d Cir. 1966), cert. denied, 386 U.S. 1035 (1967); Green v. Wolf Corp., 406 F.2d 291 (2d Cir. 1968), cert. denied, 395 U.S. 977 (1969); Korn v. Franchard Corp., 443 F.2d 1301 (2d Cir. 1971).

63 Gity of New York v. International Pipe \& Ceramics Corp., 410 F.2d 295 (2d Cir. 1969); Caceres v. International Air Transport Ass'n, 422 F.2d 141 (2d Cir. 1970); Milberg v. Western Pac. Ry. Co., 443 F.2d 1301 (2d Cir. 1971).

64370 F.2d 119 (2d Cir. 1966), cert. denied, 386 U.S. 1035 (1967). 
reviewed, is the death knell of the action, review should be allowed. ${ }^{85}$

In determining whether plaintiff's claim was "too important to be denied immediate review," however, the court appeared to focus not only on the named plaintiff, but also on the other members of the alleged class: "Dismissal of class action in the present case . . . will irreparably harm Eisen and all others similarly situated, for as we have already noted, it will for all practical purposes terminate the litigation." 68 The court thus explicitly considered relevant the fact that the other alleged class members also had claims so small that denial of the appeal would have effectively precluded their adjudication.

In Green $v$. Wolf Corp. ${ }^{67}$ a securities fraud action, the district court had dismissed the plaintiff investor's class action. As in Eisen, the Second Circuit allowed an appeal, noting that "Green obviously does not intend to press what will probably be an enormously complex and expensive action to recover less than $\$ 1,000 . " 08$ The court then directed its attention to the other members of the alleged class: "If, as here, the security in connection with which the alleged misrepresentations and violations of $10 \mathrm{~b}-5$ have been made is publicly held, a class action may well be the appropriate means for expeditious litigation of the issues, because a large number of individuals may have been injured, although no one person may have been damaged to a degree which would induce him to institute litigation solely on his own behalf." 69

In 1969, application of the death knell doctrine was again challenged in City of New York v. International Pipe \& Ceramics Corp..$^{70}$ an antitrust action against manufacturers and sellers of concrete pipe in which the City of New York had sued on its own behalf and as the representative of a class consisting of all state and municipal governments and government agencies, authorities, and subdivisions similarly situated. Departing from Eisen and Green, the Second Circuit found that the district court's dismissal of the class action was not a final judgment. Focusing exclusively on the named plaintiffs, the court stated that the dismissal was premised on the assumption that the action would, as to the named plaintiffs, proceed to a final judgment. ${ }^{71}$ Over the dissent of Judge Hays, the court found that, since " $[\mathrm{t}]$ he city and twenty seven

65 Id. at 120-21.

$66 \mathrm{Id}$. at $12 \mathrm{l}$ (emphasis added).

67 406 F.2d 291 (2d Cir. 1968), cert. denied, 395 U.S. 977 (1969).

68 Id. at 295 n.6.

69 Id. at 296 (emphasis added).

70410 F.2d 295 (2d Cir. 1969).

71 Id. at 298. 
plaintiff-intervenors with adequate resources to continue the action and with substantial amounts at stake will undoubtedly carry on,"72 the denial of class action status would not serve as the death knell of the action. Significantly, the court did not express concern about the predicament of the other members of the alleged class-a factor which had been considered relevant in Eisen and Green.

It may be argued, however, that the probable effect of dismissal on the other members of the alleged class was actually considered in International Pipe since the claims of most members were obviously substantial. ${ }^{73}$ The court was perhaps implicitly adopting the rule that, if a substantial proportion of other alleged class members have economically viable claims, the death knell doctrine should not be invoked. In his dissent, Judge Hays was not willing to distinguish International Pipe from Eisen and Green on the ground that most of the other alleged class members could fend for themselves. "Certain members of the proposed class," he noted, "have claims that are not large enough to warrant their undertaking the expense of separate law suits. For those members the order determining that the action is not maintainable as a class action has terminated the litigation."74 Judge Hays also pointed out that the named plaintiff, if successful in his individual action, would probably have no desire afterward to appeal from the class action dismissal, and that, consequently, the dismissal would probably never be appealed. ${ }^{75}$ In such situations, the denial of immediate review

72 Id. at 299. This language, standing alone, has the potential of misguiding other courts and litigants dealing with similar issues. Certainly, Eisen and Green should not have been decided differently had either of the named plaintiffs been shown to be independently wealthy. In each case, the operative factor was not the pocketbooks of the plaintifs, but rather the interplay between the potential benefits from successful litigation and the potential costs of pursuing the suit. The potential recovery of seventy dollars in Eisen and one thousand dollars in Green could not be reasonably balanced against the court costs and attorneys' fees required to litigate complex and time-consuming issues. A wealthy party no less than a poor litigant would tend to avoid an action in which the costs would outweigh any conceivable benefits.

73 Since the alleged class was made up exclusively of governmental bodies, the danger of any other member having a claim so small or being without adequate resources to obtain counsel to litigate an individual action was probably remote. The court noted that "already some 66 other actions are pending." Id. at 299.

74 Id. at $300-01$.

75 For a discussion of the reasons why a successful litigant and his attorney, after pursuing the former's individual claim to fruition, would abandon their original plan of representing a class, see Note, Interlocutory Appeals from Orders Striking Class Action Allegations, 70 Colum. L. REv. 1293-94 (1970).

[T]f the named plaintiff does appeal the order after prevailing on the merits, his success on appeal may be a dubious blessing from his point of view: he may be permitted to represent the class but be required to prosecute a new trial. For if the appellate court reverses the district court on the class action question, it may conclude at the same time that it would be improper merely to order that notice pursuant to 
would usually serve as the death knell of the class action. ${ }^{78}$

Subsequently, in Caceres $v$. International Air Transport Association, ${ }^{77}$ seven travel agents had brought an antitrust action on their own behalf and as representatives of a class of travel agents against several major international air carriers and their trade association. The Second Circuit, following International Pipe, found that the district court's class action dismissal was not a final judgment. As in International Pipe, both the named plaintiffs and a substantial proportion of other members of the alleged class had claims large enough to warrant bringing individual actions. As in Eisen and Green, however, the court focused explicitly on the probable effect of dismissal on the other alleged class members. It noted that, in both Eisen and Green, "the average claim of each member of the class was quite small. Here it is not; Judge Mansfield pointed out that the average claim alleged is $\$ 150,000$ per member."78

Viewing these four cases together, it appears that, with the possible exception of International Pipe, the court regarded as relevant the probable effect of dismissal on both the named plaintiff and the other members of the alleged class. In none of the cases, however, was the court confronted with a named plaintiff whose claim was significantly different in magnitude from those of the majority of the other alleged class members. Thus, the cases left open the question of the appealability of a class action dismissal where the claim of the named plaintiff is sufficiently large to warrant bringing an individual action, but where the majority of the other alleged class members have claims too small to pursue individually. ${ }^{79}$ This question finally arose in a pair of recent Second Gircuit cases.

Rule 23(c)(2) be sent to the members of the class without a new trial, since such a disposition of the appeal would permit members of the class to make their decision whether to join in the action at a time when they already know its outcome-a form of "one-way" intervention that the 1966 amendments were designed to prevent. Alternatively or additionally, the court may decide that such a disposition would be unfair to the defendant since it would result in a judgment against him significantly larger in amount than the liability against which he litigated his defense at the trial. Thus, the appellate court might well conclude that, despite the time and expense involved, fairness requires the ordering of a new trial. Id. at 1293-94.

76 As the court in Eisen noted, 370 F.2d at 120: "If the appeal is dismissed, not only will Eisen's claims never be adjudicated, but no appellate court will be given the chance to decide if this class action was proper under the newly amended Rule 23."

77422 F.2d 141 (2d Cir. 1970).

$78 \mathrm{Id}$. at 144 . The court also noted, id.: "While the damage claims of the seven plaintiffs here are not yet specific, enough appears in the record to justify Judge Mansfield's conclusion that no claim was of 'such a low order of magnitude that it would be unfeasible or uneconomic for the claimant to seek redress' 46 F.R.D. at 95."

79 Also unclear is how the court would deal with the opposite situation, where a class action dismissal would serve as a death knell to the named plaintiff's suit but in which the majority of the other members of the alleged class could bring economically viable 
In Korn v. Franchard Corp. and Milberg v. Western Pacific Railroad Co. ${ }^{80}$ decided together in 1971, the named plaintiffs alleged that they and a class of investors similarly situated had purchased securities in reliance on false and misleading statements made by the defendant corporations in violation of the federal securities acts. The Second Circuit permitted immediate appeal from the district court's class action dismissal in Korn, but it denied such relief in Milberg.

In articulating the general principles governing the determination of the finality of a class action dismissal, the court concluded that - " 'absent the death knell rationale relied on in Eisen-orders striking class suit allegations are not appealable' as final orders . . . ."81 The court admitted, as it had in Caceres, that the "arguments for a rule of broad appealability from refusals to designate a class are 'not without force." "s2 But, unable to formulate a limiting principle and not desiring to "augment the onrushing tide of appeals," it held steadfast to the more restrictive doctrine: "[T]he logical end of such arguments is, as we noted in Caceres, 'that an order refusing class action treatment should almost always be appealable. ..." "s3 Such a rule of broad appealability, the court stated, would run contrary to the various policies behind congressional adherence to the final judgment rule.

In deciding these two cases, the court apparently focused exclusively on the probable effect of the class action dismissal on the named plaintiff. In Korn, because the named plaintiff's claim was only $\$ 368$, the court thought the dismissal would serve as a death knell to his action. In Milberg, however, the named plaintiff's claim was at least $\$ 8,500$, which the court thought large enough to induce her to pursue individually.

Assuming, as appeared to be the case, that most of the other members of the alleged class in Milberg had relatively small claims, ${ }^{84}$ the court's decision permanently denied relief to a significant number of persons whose chance of recovery was effectively terminated by the class action dismissal. ${ }^{85}$ Furthermore, it denied class representation status to the

individual actions. From the language of the opinions, however, it seems that immediate review will follow whenever the named plaintiff can show that he "simply cannot continue his law suit alone." Korn v. Franchard Corp., 443 F.2d 1301, 1306 (2d Cir. 1971).

80443 F.2d 1301 (2d Cir. 1971).

81 Id. at 1305.

$82 I d$.

$83 \mathrm{Id}$.

84 The claim in Milberg was found substantial only by merging Mr. Milberg's claim with that of his wife and by rejecting their argument that even the merged claim was not large enough to warrant further prosecution. It is therefore probable that the claims of the other members of the alleged class were too small to pursue individually.

85 Such circumstances of fate have not usually served as ruling principles in the ad- 
party who might best perform that role-the named plaintiff with a relatively large claim and a substantial interest in the outcome of the action-solely because of the fortuitious circumstance of the named plaintiff's relatively large claim. ${ }^{86}$

\section{B. Consequences of a Broader Rule}

What has been suggested by the previous discussion is that, where the named plaintiff's claim is larger that those of the other members of the alleged class, the court, in relegating the named plaintiff to a suit in his individual capacity, may effectively foreclose for the other alleged class members an adjudication of their claims. Consequently, the named plaintiff should have a right under section 1291 to appeal a class action dismissal whenever it would effectively foreclose for any other alleged class member an adjudication of his claim, and not solely when the dismissal has left the named plaintiff without an economically viable individual action. Three consequences of this proposal remain to be considered.

The first concerns the effectiveness of the rule of appealability under the present death knell doctrine in facilitating speedy and efficient resolution of controversies. If the statute of limitations has not run, ${ }^{87}$ then presumably, upon dismissal of the large-claim plaintiff's class action, those members of the alleged class with small claims could bring their own class actions..$^{88}$ If they did so, additional burdens would be

judication of rights among parties. There are some situations, however, in which the size of the named plaintiff's claim is an operative factor. For diversity jurisdiction, for example, it is necessary that the named plaintiffs' aggregate claim be greater than ten thousand dollars. 28 U.S.C. § 1332 (1970); see note 11 supra.

86 In those cases in which the motivating force behind the class action is the attorney rather than the named plaintiff, however, a strong argument can be made that the only important factor is the size of potential attorneys' fees and not the size of the named plaintiff's claim.

87 Although the law is not entirely clear, because the class action under the revised rule 23 is binding on all class members, commencement of the original suit by the named plaintiff should toll the statute of limitations with respect to their claims. Esplin v. Hirschi, 402 F.2d 94, 101 n.14 (10th Cir. 1968); Minnesota v. United States Steel Corp., 44 F.R.D. 559, 572-76 (D. Minn. 1968); Comment, Class Actions Under New Rule 23 and Federal Statutes of Limitation: A Study of Conficting Rationale, 13 VIL.. L. REv. 370 (1968). Such a result is also called for if the right to bring the suit as a class action is denied, an act which could take place anytime until a final judgment on the merits. FED. R. Crv. P. 28(c)(1); 3B J. MOORE, supra note 7, I 23.50. To do otherwise would force the class members to file individual protective suits pending determination of the original class action request. Philadelphia Electric Co. v. Anaconda Am. Brass Co., 43 F.R.D. 452, 460-61 (E.D. Pa. 1968); 3B J. MoORE, supra note 7, If 23.90. Comment, Spurious Class Actions Based upon Securities Frauds Under the Revised Federal Rules of Civil Procedure, 35 FordHAM L. REv. 295, 308-09 (1966).

88 Obviously, if the statute of limitations has run, all other members of the alleged 
placed on the judicial machinery to process the suits. Ironically, the implicit purpose of narrow application of the death knell doctrine -protection of the courts of appeals from being overwhelmed by interlocutory appeals-would be frustrated by the consequent proliferation of new class actions in the district courts. Furthermore, if the new class actions by small-claim named plaintiffs were found not maintainable, there would be immediate review in the court of appeals under the death knell doctrine. Adopting a broader rule of appealability, on the other hand, would tend to decrease the number of suits and appeals by insuring that the class action issue could be promptly and conclusively resolved by the court of appeals in the first instance regardless of the size of the named plaintiff's claim. ${ }^{89}$

The second consideration relates to the possibility that the class action dismissal will never be appealed. While criticism of the death knell doctrine has thus far focused on the reluctance of the named plaintiff who has prevailed on the merits in his individual capacity to appeal from the class action dismissal, it should be observed that, when the class action was first dismissed, the named plaintiff was in no way obligated at that early juncture to appeal from the order. Yet this is usually not a problem since the plaintiff's attorney is often the real motivating force behind the class action. Unless the attorney is certain that a large damage recovery is possible, he may be unwilling to proceed to a trial on the merits. Concern about the eventual size of the fund for attorneys' fees will therefore usually insure an early appeal. Where this is not the situation, of course, the other alleged class members must bring another individual or class action on their own initiative.90

class who relied on the class action will upon its dismissal be forever barred from litigating their claims, whether large or not. For them, an appeal of the dismissal would be the only hope of reviving their interests.

89 It may be, however, that, under the death knell doctrine as presently construed, cautious attorneys will hesitate to bring a class action except where the named plaintiff's claim is small enough to insure immediate review in the event the district court dismisses the class action. Consequently, allowing appeal by named plaintiffs with large individual claims might have only a de minimis effect on the number of appeals.

90 Such further litigation might be avoided if the other alleged class members were permitted to intervene in the original suit for the purpose of appealing the class action dismissal. Practical and legal difficulties would inhere, however, in an attempt to utilize that means of redress.

FED. R. Crv. P. 24 provides:

INTERVENTION

(a) Intervention of Right. Upon timely application anyone shall be permitted to intervene in an action: (I) when a statute of the United States confers an unconditional right to intervene; or (2) when the applicant claims an interest relating to the property or transaction which is the subject of the action and he is so situated that the disposition of the action may as a practical matter impair or impede his 
Finally, a broad rule of appealability would further serve judicial economy because the immediate appellate determination of the class action status would significantly influence how all parties to the action, including the district court, will proceed at trial. Presumably, a class action involving substantial damages would be litigated differently than a small individual claim.91 $\mathrm{A}$ broad rule of appealability would permit the court of appeals to play a larger role in shaping the class action remedy by devising standards to guide the district court's broad

ability to protect that interest, unless the applicant's interest is adequately represented by existing parties.

(b) Permissive Intervention. Upon timely application anyone may be permitted to intervene in an action: (1) when a statute of the United States confers a conditional right to intervene; or (2) when an applicant's claim or defense and the main action have a question of law or fact in common. When a party to an action relies for ground of claim or defense upon any statute or executive order administered by a federal or state governmental officer or agency or upon any regulation, order, requirement or agreement issued or made pursuant to the statute or executive order, the officer or agency upon timely application may be permitted to intervene in the action. In exercising its discretion the court shall consider whether the intervention will unduly delay or prejudice the adjudication of the rights of the original parties.

(c) Procedure. A person desiring to intervene shall serve a motion to intervene upon the parties as provided in Rule 5. The motion shall state the grounds therefor and shall be accompanied by a pleading setting forth the claim or defense for which intervention is sought. The same procedure shall be followed when a statute of the United States gives a right to intervene. When the constitutionality of an act of Congress affecting the public interest is drawn in question in any action to which the United States or an officer, agency, or employee thereof is not a party, the court shall notify the Attorney General of the United States as provided in Title 28, U.S.C. \& 2403.

The rule requires that a party seeking intervention as of right show three things: (1) that he has an interest relating to the property or transaction which is the subject of the action, (2) that the disposition of the action may as a practical matter impair or impede his ability to protect the interest, and (3) that the interest is not adequately represented by the present parties.

The most settled type of case for permissive intervention, which is granted at the trial court's discretion and is usually considered a nonappealable interlocutory order, is that in which the intervenor has a claim against the defendant similar to or identical with the plaintiff's claim. E.g., United States v. Fidelity \& Deposit Co., 22 F.R.D. 248 (M.D. Pa. 1958).

Within the context of the death knell doctrine, the important question is whether or not, under rules 23 (d) and 24, a showing could be made that representation by the named plaintiff may be inadequate where he does not have a right of immediate appeal from a district court dismissal of the class action. See generally 3B J. MOORE, supra note 7, II 23.90[2], 24.01-.20.

91 As Judge Rosenn, dissenting in Hackett v. General Host Corp., No. 19,320 (3d Cir., Jan. 14, 1972), noted:

Furthermore, the district court's denial of the right to proceed as a class action has certainly affected the subsequent conduct of the litigation. Assuming that the suit will continue on the part of the appellant in her individual capacity, it is inconceivable that either the lawyers or the court will give a nine dollar suit the same consideration and attention due a class action involving hundreds of thousands of persons and many millions of dollars in potential damages. If nothing else it would be a waste of judicial resources to allocate extensive time to antitrust litigation over this paltry sum. 
discretion under rule 23 without placing further strain on the one final judgment rule as it has been previously interpreted.

Alan J. Howard

Cary I. Klafter 